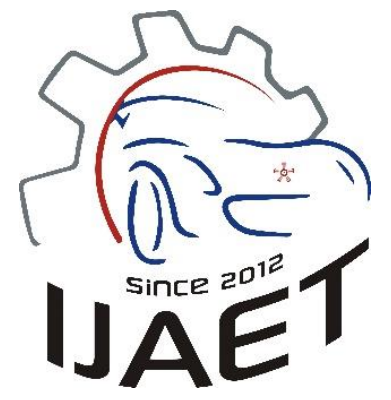

e-ISSN: 2146 - 9067

International Journal of Automotive

Engineering and Technologies

journal homepage:

https://dergipark.org.tr/en/pub/ijaet

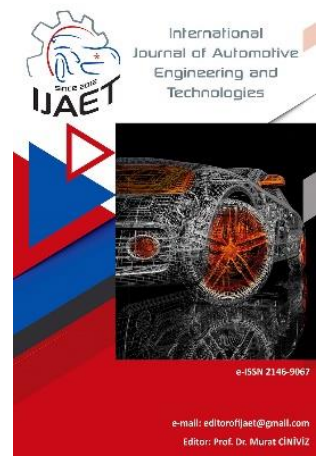

Original Research Article

\title{
Calculation of heat transfer from the bottom of a coach to the passenger compartment
}

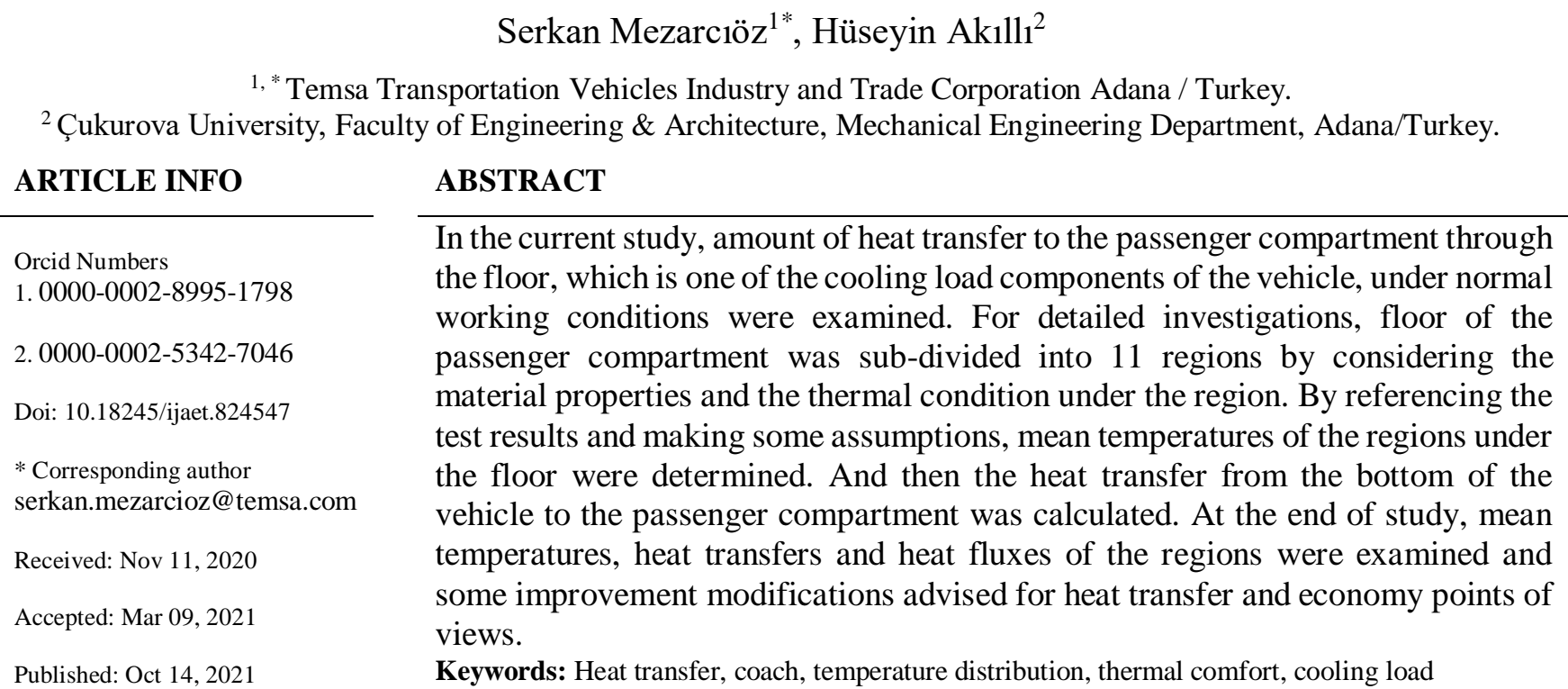

Published by Editorial Board

Members of IJAET

(C) This article is distributed by

Turk Journal Park System under

the CC 4.0 terms and conditions.

\section{Introduction}

Thermal protection is increasingly important in the development process of passenger cars. Tightly packaged engine compartments and strongly increased engine power demand extensive testing and analysis [1].

Modern man's desire for mobility has been a major factor in technical developments. The bus (from Latin omnibus: "for all") has played a significant role in this development. Within the introduction of enclosed bodywork, passengers were given a certain level of comfort. Today, buses still account for a major portion of road transport. The most convincing argument to the passenger in favor of bus travel, however, is the comfort offered, and the interior climate plays a key role here [2].

An important factor affecting the comfort of bus passengers is the heat transfer from the engine compartment through the floor of the passenger compartment. Especially in the summer times, this heat negatively affects the comfort of the passengers.

All of the engineers know that, the temperature of the regions under a coach is higher than the passenger compartment and as a result of this; 
some amount of heat is transferred to the passenger compartment. But in literature there is no information about the temperature levels of a coach under side. With this study, it is aimed to determine these temperatures and the heat transfer amount to the passenger compartment. On the other hand some researchers conducted studies on under hood thermal investigations for automobiles, and trucks. Also some studies conducted to predict the cooling load of a bus.

Büyükalaca et al., (2011) used Radiant Time Series (RTS) method for the calculation of cooling load of a bus. In the study, they introduced Radiant Time Series (RTS) method briefly and gave the important points for the application of the method to a bus [3].

Fournier and Digges (2004) investigated 4 different models of automobiles under hood temperatures in their study with a test procedure similar to present study. In their study, 11 thermo-couples were installed to 4 different vehicles' under hood and measurements were done with 3 different test conditions, which are stationary, constant speed driving and uphill driving [4].

Binner et al. (2006), in their study investigated the under hood temperature distribution of a sport car under maximum speed and low speed uphill climbing test conditions [1].

Kulkarni et al. (2012) conducted a study on under hood flow management of heavy commercial vehicle to improve thermal performance. In the study under hood flow management for $25 \mathrm{~T}$ truck has been carried out by flow analysis by CFD method using commercial software. As a result of this study they improved velocity and mass flow rate of the air passing through the radiator, and engine room of a truck. Since the airflow around the engine was improved, at the end of modifications, heat transfer to the driver cabin was decreased and heat rejection on radiator and exhaust manifold increased [5].

A computational study was conducted by Xiao et al. (2008), in order to characterize the heat transfers in a sedan vehicle underbody and the exhaust system [6].

Reddy et al., (2019) has conducted a study on analysis of air conditioning system used in buses. The aim of the study was to analyze the performance of a bus shell by considering identifying practical solutions in order to reduce the impact of air conditioning on bus, consumption and, therefore, on air pollution. The analysis was carried considering several parameters, including passenger capacity, local climatic conditions, and fuel consumptions. For the analysis, a bus with passenger capacity of 60 people was selected and then its heat load capacity was determined by considering different conditions like seasons and various loads [7].

Temperature distribution of engine room of a $12-\mathrm{m}$ coach in different driving conditions was examined by Mezarciöz, (2018). For detailed investigations, engine room was subdivided into six regions by considering the mechanical component layout and thermal condition of the regions. For determination of the temperatures, a test vehicle, which was equipped with 14 thermocouples, tested under three different test conditions. These are constant high speed, uphill climbing and stationary test conditions. At the end of the study, the temperatures of each region under three different driving conditions were determined [8].

In this study, it is focused on the temperatures of the regions under the passenger compartment and amount of heat transfer to the passenger compartment by conduction and convection under regular working conditions. Also some improvements are advised to improve the heat isolation and cost reduction.

\section{Material and method}

In the present study, the amount of heat transfer from the bottom of a 12-m length coach to the passenger compartment under regular operational conditions was calculated by considering the components that can be assumed as a heat source under the vehicle like, engine, transmission, exhaust muffler, axles etc. The bottom of the passenger compartment subdivided into 11 regions by considering the material properties (material, thickness and thermal conductivity) and predicted mean temperature under the regions. Then, all the regions examined in detail. Codes and names of the regions can be seen in Figure 1 and Table 1 respectively.

In order to calculate the heat transfer mentioned above, firstly the thermal properties of the heat transfer areas, in other words, the section properties of the passenger compartment must 
be specified.

The material properties of each section are given in the Tables from 2 to 6 . Also section view of region FL1 can be seen as an example in Figure 2.

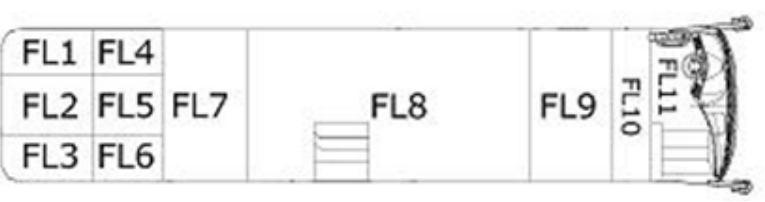

Figure 1. Codes of the regions

Table 1. The names and codes of the regions

\begin{tabular}{ll}
\hline Detail Region Name & Detail Region \\
Code & \\
\hline
\end{tabular}

\begin{tabular}{ll}
\hline Above the Radiator & FL1 \\
Above the Engine & FL2 \\
Above the Exhaust & FL3 \\
Above the Rear Left Luggage & FL4 \\
Above the Transmission & FL5 \\
Above the Battery & FL6 \\
Above the Rear Axle & FL7 \\
Above the Luggage & FL8 \\
Compartment & FL9 \\
Above the Front Axle & FL10 \\
Above the Fuel Tank & FL11 \\
Below the Driver Platform & Floor Linoleum \\
\hline & Plywood \\
\hline & Mloor Wood \\
\hline & Melamine Foam \\
\hline Room & \\
\hline & \\
\hline
\end{tabular}

Figure 2. Section view of region FL1.

Table 2. Material properties table for the regions FL1, FL2, FL3 and FL6

\begin{tabular}{|c|c|c|c|c|}
\hline No & $\begin{array}{c}\text { Section } \\
\text { Name }\end{array}$ & Material & $\begin{array}{c}\text { Thickness } \\
\text { (m) }\end{array}$ & $\begin{array}{c}\text { Thermal } \\
\text { Conductivity } \\
(\mathrm{W} / \mathrm{mK})\end{array}$ \\
\hline 1 & $\begin{array}{l}\text { Floor } \\
\text { Linoleum }\end{array}$ & PVC & 0.002 & 0.116 \\
\hline 2 & $\begin{array}{l}\text { Floor } \\
\text { Wood } \\
\text { Main }\end{array}$ & Plywood & 0.015 & 0.130 \\
\hline 3 & $\begin{array}{l}\text { Insulation } \\
\text { of Engine } \\
\text { Room }\end{array}$ & $\begin{array}{l}\text { Melamine } \\
\text { Foam }\end{array}$ & 0.054 & 0.040 \\
\hline 4 & $\begin{array}{l}\text { Insulation } \\
\text { Cover of } \\
\text { Engine } \\
\text { Room }\end{array}$ & $\begin{array}{c}\text { Melamine } \\
\text { Foam }\end{array}$ & 0.020 & 0.040 \\
\hline
\end{tabular}

Thermal conductivity of the materials are taken from Yilmaz (1999) [9].
Table 3. Material properties table for region FL4

\begin{tabular}{lll}
\hline \multicolumn{1}{c}{ Number } & \multicolumn{1}{c}{$\mathbf{1}$} & \multicolumn{1}{c}{$\mathbf{2}$} \\
\hline Section Name & Floor Linoleum & Floor \\
Material & PVC & Wood \\
Thickness (m) & 0.002 & 0.016 \\
Thermal Conductivity & 0.112 & 0.130 \\
(W/mK) & & \\
\hline
\end{tabular}

Table 4. Material properties table for region FL5

\begin{tabular}{llll}
\hline \multicolumn{1}{c}{ Number } & \multicolumn{1}{c}{$\mathbf{1}$} & \multicolumn{1}{c}{$\mathbf{2}$} & \multicolumn{1}{c}{$\mathbf{3}$} \\
\hline Section Name & Floor & Floor & Metal \\
& Linoleum & Wood & Sheet \\
Material & PVC & Plywood & Steel \\
$\begin{array}{l}\text { Thickness (m) } \\
\text { Thermal }\end{array}$ & 0.002 & 0.015 & 0.002 \\
$\begin{array}{l}\text { Conductivity } \\
\text { (W/mK) }\end{array}$ & 0.116 & 0.130 & 53.0 \\
\hline
\end{tabular}

Table 5. Material properties table for region FL7

\begin{tabular}{|c|c|c|c|}
\hline Number & 1 & 2 & 3 \\
\hline Section Name & $\begin{array}{l}\text { Floor } \\
\text { Linoleum }\end{array}$ & $\begin{array}{l}\text { Floor } \\
\text { Wood }\end{array}$ & $\begin{array}{l}\text { Main } \\
\text { Insulation } \\
\text { of Engine } \\
\text { Room }\end{array}$ \\
\hline Material & PVC & Plywood & $\begin{array}{l}\text { Melamine } \\
\text { Foam }\end{array}$ \\
\hline $\begin{array}{l}\text { Thickness (m) } \\
\text { Thermal }\end{array}$ & 0.002 & 0.015 & 0.054 \\
\hline $\begin{array}{l}\text { Conductivity } \\
\text { (W/mK) }\end{array}$ & 0.116 & 0.130 & 0.040 \\
\hline
\end{tabular}

Table 6. Material properties table for region FL8, FL9, FL10, FL11

\begin{tabular}{lll}
\hline \multicolumn{1}{c}{ Number } & $\mathbf{1}$ & $\mathbf{2}$ \\
\hline Section Name & Floor & Floor \\
Material & Linoleum & Wood \\
Thickness (m) & PVC & Plywood \\
Thermal & 0.002 & 0.015 \\
Conductivity $(\mathbf{W} / \mathbf{m K})$ & 0.116 & 0.130 \\
\hline
\end{tabular}

As can be seen from the tables, while in the regions, accommodating heat and sound sources like engine, transmission, radiator and exhaust muffler, named as engine room, double layer special isolation materials and $15 \mathrm{~mm}$ thickness plywood are employed, in the rear axle region single layer isolation material is employed. Also in the front axle and luggage room regions only $12 \mathrm{~mm}$ thickness plywood is used as a separator without any extra isolation.

It can be assumed that a coach is generally driven in high speed in highway conditions. Also, the vehicle is forced to climb uphill in some portion of this highway condition. Additionally, a bus can wait in idle in a small time period of life. So the life cycle of a coach 
can be assumed as $70 \%$ of highway condition, $20 \%$ of uphill condition and $10 \%$ of idle condition.

In order to determine the temperatures in these conditions a study was conducted by Mezarciöz (2015). In the study a test vehicle equipped with 31 thermo-couples (Figure 3) tested under these test conditions [10].

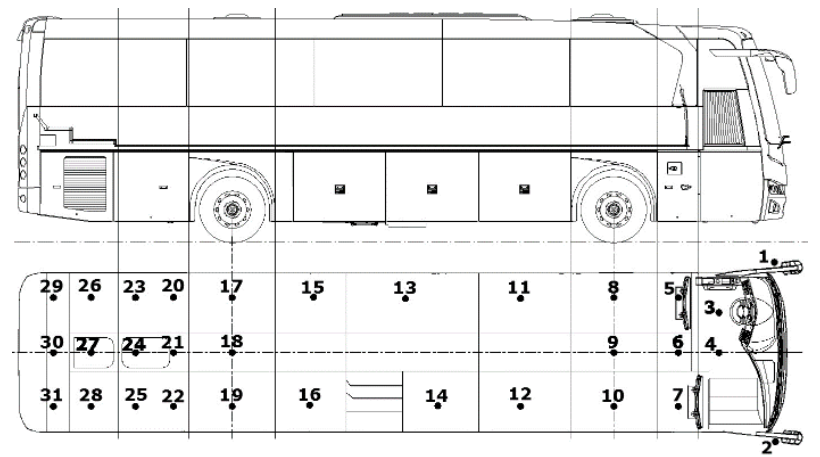

Figure 3. Thermo-couple installation plan

Here, the thermo-couples numbered 1 and 2 were mounted to the side mirrors of the vehicle and used to measure the outside temperature during the tests.

In high speed test condition, test vehicle was driven in a straight highway with a constant speed of $100 \mathrm{~km} / \mathrm{h}$ in the last gear step of the transmission and the temperatures were recorded for $50 \mathrm{~km}$. In ramp climbing test condition, measurements were taken while the test vehicle was forced to climb in a ramp with a slope of about $15 \%$ at $30 \mathrm{~km} / \mathrm{h}$. In stationary test condition, the test vehicle was parked in a place where it would be exposed to direct sunlight, and engine room temperature measurements were taken while idling. These measurements were taken under the conditions of $35^{\circ} \mathrm{C}$ of average outdoor temperature.

In all test conditions, a period of time was waited until the temperatures were stable. Data was recorded in high speed and stationary test conditions in 30 minutes and in ramp climbing conditions 10 minutes. Under all test conditions, the average outdoor temperature was recorded as $35^{\circ} \mathrm{C}$.

Cabin temperature of the vehicle is assumed as $24{ }^{\circ} \mathrm{C}$ by considering the summer comfort conditions by SAE J1503 and Temsa (2007) [11, 12].

For the calculation of heat transfer coefficients the following procedure was used by considering the heat transfer section properties, inside and outside temperatures.

Total heat transfer coefficient was calculated by employing Equation 1.

$\frac{1}{U}=\frac{1}{h_{\text {in }}}+\frac{s_{1}}{k_{1}}+\frac{s_{2}}{k_{2}}+\ldots+\frac{s_{n}}{k_{n}}+\frac{1}{h_{\text {out }}}$

Here inner surface heat transfer coefficient is taken from ASHREA standards, as $8 \mathrm{~W} / \mathrm{mK}$ for free convection conditions [13].

For the calculation of $\mathrm{h}_{\text {out }}$ values equation 2 was employed.

$h_{\text {out }}=\frac{N u \times k}{L_{k}}$

Nusselt Number can be calculated by using Equation 3 [9].

$$
N u=\sqrt{\left(N u_{L, \text { Lam }}\right)^{2}+\left(N u_{L, T u r}\right)^{2}}
$$

Local Nusselt Numbers can be calculated by using Equations 4 and 5 [9].

$$
\begin{aligned}
& N u_{L, L a m}=0,664 x \operatorname{Re}^{1 / 2} x \operatorname{Pr}^{1 / 3} \\
& N u_{L, T u r}=\frac{0,037 \times \operatorname{Re}^{0,8} \times \operatorname{Pr}}{1+2,443 \operatorname{Re}^{-0,1} \times\left(\operatorname{Pr}^{2 / 3}-1\right)}
\end{aligned}
$$

By using the dry air properties in average temperature, Reynolds and Prandtl numbers can be calculated by employing Equations 6 and 7 [9].

$$
\begin{aligned}
& \operatorname{Re}=\frac{v \times L_{k}}{v} \\
& \operatorname{Pr}==\frac{v}{\frac{k}{\left(c_{p} \times \rho\right)}}
\end{aligned}
$$

For the dry air properties in average temperature, the following equations were used [9].

$$
\begin{aligned}
& k=0,02418 \times\left(\frac{273+T_{\text {ort }}}{273}\right)^{0,85} \\
& c_{p}=1,005+0,006 \times\left(\frac{T_{\text {ort }}}{100}\right)^{1,73} \\
& \rho=348,1 \times\left(\frac{P}{273+T_{\text {ort }}}\right)
\end{aligned}
$$




$$
\begin{aligned}
& \eta=1,724 \times 10^{-5} \times\left(\frac{273+T_{\text {ort }}}{273}\right)^{0,77} \\
& v=\frac{\eta}{\rho}
\end{aligned}
$$

At the end of these preparations, the amount of heat transfer from each of the regions to the passenger compartment was calculated by using Equation 13.

$Q=U \cdot F \cdot \Delta T$

\section{Results and Discussions}

As a result of test results and assumptions, the average temperatures of the regions under the vehicle floor were determined as shown in Table 7.

Table 7. Average temperatures of the regions under the

\begin{tabular}{|c|c|c|c|c|}
\hline \multirow{2}{*}{$\begin{array}{l}\text { Detail Region } \\
\text { Name }\end{array}$} & $\begin{array}{c}\text { Highway } \\
(\% 70)\end{array}$ & $\begin{array}{l}\text { Uphill } \\
(\% 20)\end{array}$ & $\begin{array}{l}\text { Idle } \\
(\% 10)\end{array}$ & \multirow{2}{*}{$\begin{array}{c}\text { Weighted } \\
\text { Average } \\
\text { Temperature } \\
\left({ }^{\circ} \mathrm{C}\right)\end{array}$} \\
\hline & $\begin{array}{l}\text { Temp } \\
\left({ }^{\circ} \mathrm{C}\right)\end{array}$ & $\begin{array}{c}\text { Temp } \\
\left({ }^{\circ} \mathrm{C}\right)\end{array}$ & $\begin{array}{c}\text { Temp } \\
\left({ }^{\circ} \mathrm{C}\right)\end{array}$ & \\
\hline $\begin{array}{l}\text { Above the } \\
\text { Radiator }\end{array}$ & 71.2 & 79.5 & 54.3 & 71.2 \\
\hline $\begin{array}{l}\text { Above the } \\
\text { Engine }\end{array}$ & 72.0 & 80.4 & 56.3 & 72.1 \\
\hline $\begin{array}{l}\text { Above the } \\
\text { Exhaust }\end{array}$ & 74.8 & 90.5 & 66.7 & 77.1 \\
\hline $\begin{array}{l}\text { Above the Rear } \\
\text { Left Luggage }\end{array}$ & 55.1 & 57.3 & 57.0 & 55.7 \\
\hline $\begin{array}{l}\text { Above the } \\
\text { Transmission }\end{array}$ & 47.5 & 61.5 & 59.2 & 51.5 \\
\hline $\begin{array}{l}\text { Above the } \\
\text { battery }\end{array}$ & 54.7 & 57.8 & 56.6 & 55.5 \\
\hline $\begin{array}{l}\text { Above the Rear } \\
\text { Axle }\end{array}$ & 41.8 & 38.4 & 45.3 & 41.5 \\
\hline $\begin{array}{l}\text { Above the } \\
\text { Luggage Com. }\end{array}$ & 32.4 & 31.5 & 31.7 & 32.2 \\
\hline $\begin{array}{l}\text { Above the Front } \\
\text { Axle }\end{array}$ & 36.3 & 34.0 & 36.6 & 35.9 \\
\hline $\begin{array}{l}\text { Above the Fuel } \\
\text { Tank }\end{array}$ & 36.5 & 34.3 & 36.0 & 36.0 \\
\hline $\begin{array}{l}\text { Below the Driver } \\
\text { Platform }\end{array}$ & 35.4 & 33.8 & 34.8 & 35.0 \\
\hline
\end{tabular}
vehicle floor [10]

Heat transfer from each of the regions to the passenger compartment was calculated by means of the calculation tables, which one of a sample is shown in Table 8.

As can be seen from the sample calculation table (Table 8) Reynolds Number is over 500.000, so it can be said that the flow under the passenger compartment is turbulent.

The procedure explained above to calculate the amount of heat transfer was followed for each of the 11 regions. Then, the results were shown in Figure 4 and tabulated in Table 9.

Table 8: Sample calculation table of convective and

\begin{tabular}{|c|c|c|c|c|c|}
\hline \multicolumn{6}{|c|}{ CALCULATION TABLE OF HEAT GAIN BY CONDUCTION AND CONVECTION } \\
\hline \multicolumn{2}{|c|}{ Main Region Name } & Vehicle Floor & \multirow{3}{*}{$\begin{array}{l}\text { FL1 FLL } \\
\text { FL2 FLL FL7 } \\
\text { FL3 FLL }\end{array}$} & \multirow{2}{*}{${ }^{F L B}$} & \multirow{3}{*}{ FLg है? } \\
\hline \multicolumn{2}{|c|}{ Main Region Code } & $\mathrm{FL}$ & & & \\
\hline \multicolumn{2}{|c|}{ Detail Region Name } & Above the Radiator & & & \\
\hline \multicolumn{2}{|c|}{ Detail Region Code } & FL1 & & & \\
\hline \multicolumn{2}{|c|}{ Heat Transfer Surface Area (m2) } & 0,964 & & & \\
\hline \multicolumn{3}{|c|}{ Definition } & Notation & Value & Unit \\
\hline \multicolumn{3}{|c|}{ Inside Temperature } & $T_{\text {in }}$ & 24 & ${ }^{\circ} \mathrm{C}$ \\
\hline \multicolumn{3}{|c|}{ Inside Conventional Heat Transfer Coefficient } & $h_{i n}$ & 8 & $\mathrm{~W} / \mathrm{m}^{2} \mathrm{~K}$ \\
\hline \multicolumn{3}{|c|}{ Outside Temperature } & $T_{\text {out }}$ & 71,2 & ${ }^{\circ} \mathrm{C}$ \\
\hline \multicolumn{3}{|c|}{ Mean Temperature } & $T_{\text {avg }}$ & 47,6 & ${ }^{\circ} \mathrm{C}$ \\
\hline \multicolumn{3}{|c|}{ Temperature Difference } & $\Delta \mathrm{T}$ & 47,2 & ${ }^{\circ} \mathrm{C}$ \\
\hline \multicolumn{3}{|c|}{ Characteristic Length } & $L_{\mathrm{K}}$ & 0,7 & $\mathrm{~m}$ \\
\hline \multicolumn{3}{|c|}{ Outside Air Velocity } & u & 50 & $\mathrm{~km} / \mathrm{h}$ \\
\hline \multicolumn{3}{|c|}{ Outside Air Velocity } & u & 13,9 & $\mathrm{~m} / \mathrm{s}$ \\
\hline \multicolumn{6}{|c|}{ REGIONAL SECTION OF HEAT TRANSFER } \\
\hline \multicolumn{6}{|c|}{ 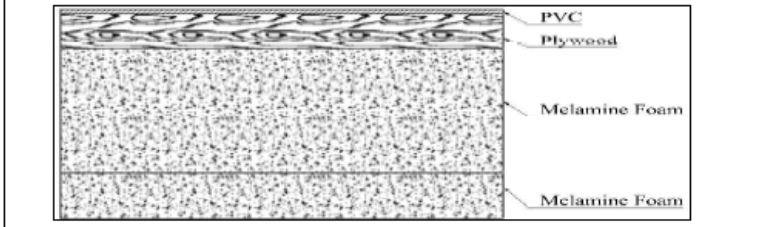 } \\
\hline S.N. & Section Name & Material & \begin{tabular}{|c|} 
Thickness \\
$(\mathrm{m})$
\end{tabular} & \multicolumn{2}{|c|}{$\begin{array}{l}\text { Coefficient of Therma } \\
\text { Conductivity }(\mathrm{W} / \mathrm{mK})\end{array}$} \\
\hline & Floor Lineleum & PVC & 0,002 & \multicolumn{2}{|l|}{0,116} \\
\hline & Floor Wood & Plywood & 0,015 & \multirow{2}{*}{\multicolumn{2}{|c|}{$\frac{0,040}{0,040}$}} \\
\hline & Main Insulation of Engine Room & Melamine Foam & 0,054 & & \\
\hline & Insulation Cover of Engine Room & Melamine Foam & 0,020 & \multicolumn{2}{|c|}{0,040} \\
\hline \multicolumn{6}{|c|}{ PROPERTIES OF DRY AIR AT MEAN TEMPERATURE } \\
\hline \multicolumn{3}{|c|}{ Thermal Conductivity } & $\mathrm{k}$ & 0,028 & W/mK \\
\hline \multicolumn{3}{|c|}{ Specific Heat } & $c_{p}$ & $1.006,661$ & $\mathrm{~J} / \mathrm{kgK}$ \\
\hline \multicolumn{3}{|c|}{ Density } & $\rho$ & 1,086 & $\mathrm{~kg} / \mathrm{m}^{3}$ \\
\hline Dynar & iic Viscosity & & $\mu$ & $1,95 \mathrm{E}-05$ & $\mathrm{~kg} / \mathrm{m} / \mathrm{s}$ \\
\hline Kinen & atic Viscosity & & $\mathrm{v}$ & \begin{tabular}{l|l}
$1,80 \mathrm{E}-05$ \\
\end{tabular} & $\mathrm{~m}^{2} / \mathrm{s}$ \\
\hline Prand & Number & & $\mathrm{Pr}$ & 0,71 & \\
\hline Reyn & Ids Number & & $\operatorname{Re}$ & \begin{tabular}{|l|}
$541.030,96$ \\
\end{tabular} & \\
\hline Local & Laminar Nusselt Number & & $\mathrm{Nu}_{\text {LLam }}$ & 411,12 & - \\
\hline Local & Turbulant Nusselt Number & & $\mathrm{Nu}_{1, \mathrm{Tu}}$ & $1.168,41$ & - \\
\hline Nusse & It Number & & $\mathrm{Nu}$ & $1.238,63$ & \\
\hline Outdo & or Conventional Heat Transfer Co & efficient & hout & 57,05 & $\mathrm{~W} / \mathrm{m}^{2} \mathrm{~K}$ \\
\hline Overa & $\|$ Heat Transfer Coefficient & & $\mathrm{u}$ & 0,47 & $\mathrm{~W} / \mathrm{m}^{2} \mathrm{~K}$ \\
\hline Total & Heat Transfer (Convection + Cond & uction) & $\bar{Q}$ & 21,41 & $\mathrm{~W}$ \\
\hline
\end{tabular}
conductive heat transfer

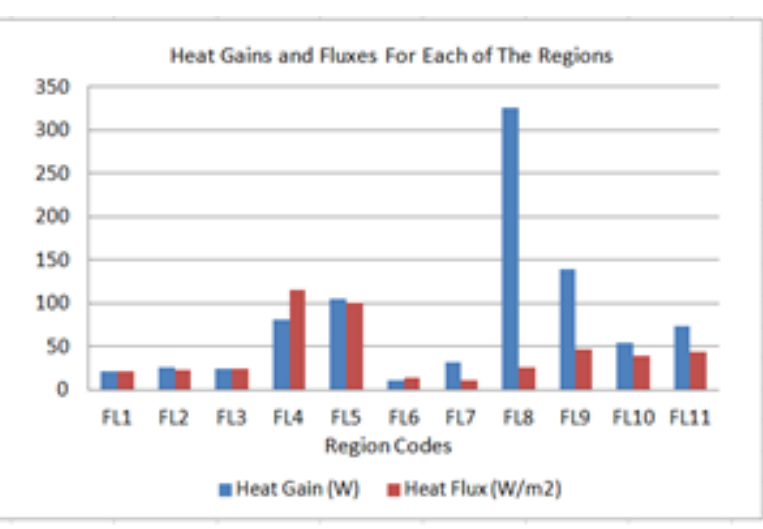

Figure 4. Heat gains and fluxes for each of the regions

Table 10 shows the relationship between climatic zones, physiological needs and the demands made on air conditioning performance based on a tour coach with a length of up to 12 $\mathrm{m}[2]$.

As can be seen from Table 10, total cooling load of a coach operating in warm temperature climatic zone is $32 \mathrm{~kW}$, also the test vehicle has a $32-\mathrm{kW}$ A/C unit. Here it can be understood 
that, the cooling load originated by the bottom of the passenger compartment is only $3 \%$ of the total cooling load of the vehicle. Here it can be seen that, the heat transfer from the bottom of the coach has a little percentage in total cooling load. The reason for this small rate is the efficiency of the isolation material (double layer and made of melamine foam) employed in the engine room. Although the main usage aim of this isolation is to reduce the noise coming from the engine room, it is also seen that current isolation materials are very efficient from the heat isolation point of view.

Table 9. Amount of heat transfer from vehicle floor region

\begin{tabular}{|c|c|c|c|}
\hline Region Name & $\begin{array}{c}\text { Region } \\
\text { Code }\end{array}$ & $\begin{array}{c}\text { Heat } \\
\text { Gain } \\
\text { (Watt) }\end{array}$ & $\begin{array}{c}\text { Heat Flux } \\
\left(\mathrm{W} / \mathbf{m}^{2}\right)\end{array}$ \\
\hline Above the Radiator & FL1 & 21.4 & 22.2 \\
\hline Above the Engine & FL2 & 26.0 & 22.6 \\
\hline Above the Exhaust & FL3 & 24.1 & 25.0 \\
\hline $\begin{array}{l}\text { Above the Rear Left } \\
\text { Luggage }\end{array}$ & FL4 & 80.9 & 114.9 \\
\hline $\begin{array}{l}\text { Above the } \\
\text { Transmission }\end{array}$ & FL5 & 105.5 & 100.0 \\
\hline Above the Battery & FL6 & 11.6 & 14.8 \\
\hline Above the Rear Axle & FL7 & 32.2 & 10.8 \\
\hline $\begin{array}{l}\text { Above the Luggage } \\
\text { Compartment }\end{array}$ & FL8 & 325.4 & 25.9 \\
\hline Above the Front Axle & FL9 & 140.1 & 46.9 \\
\hline Above the Fuel Tank & FL10 & 53.9 & 39.9 \\
\hline $\begin{array}{l}\text { Below the Driver } \\
\text { Platform }\end{array}$ & FL11 & 73.3 & 43.4 \\
\hline Vehicle Floor & FL & 894.4 & 32.9 \\
\hline
\end{tabular}

Table 10. A/C power requirements in relation to the climatic region and the physiological perceptions of the passengers [2].

\begin{tabular}{|c|c|c|c|c|}
\hline $\begin{array}{l}\text { Climate } \\
\text { Zone }\end{array}$ & Desire for... & $\begin{array}{l}\text { Cooling } \\
\text { Capacity }\end{array}$ & $\begin{array}{l}\text { Heating } \\
\text { Capacity }\end{array}$ & $\begin{array}{l}\text { Fres } \\
\text { h air } \\
\text { Flap }\end{array}$ \\
\hline $\begin{array}{c}\text { Tropical rain } \\
\text { and dry } \\
\text { climates }\end{array}$ & $\begin{array}{c}\text {... Perceptibly } \\
\text { cool and cold air } \\
\text { movement, } \\
\text { partial } \\
\text { dehumidificatio } \\
\text { n, often only } \\
\text { recirculated air }\end{array}$ & $44 \mathrm{~kW}$ & - & No \\
\hline $\begin{array}{l}\text { Warm } \\
\text { temperate } \\
\text { climate, } \\
\text { continental } \\
\text { climate, dry } \\
\text { period in } \\
\text { summer }\end{array}$ & $\begin{array}{c}\text {... Heating } \\
\text { depending on } \\
\text { region, } \\
\text { perceptible } \\
\text { ventilation, } \\
\text { recirculated or } \\
\text { fresh air portion }\end{array}$ & $39 \mathrm{~kW}$ & $32 \mathrm{~kW}$ & Yes \\
\hline $\begin{array}{c}\text { Warm } \\
\text { temperate } \\
\text { climate, cold } \\
\text { winter, rain }\end{array}$ & $\begin{array}{c}\text {... in part higher } \\
\text { heating output, } \\
\text { low air flow, } \\
\text { perceptible } \\
\text { cooling in } \\
\text { summer }\end{array}$ & $32 \mathrm{~kW}$ & $38 \mathrm{~kW}$ & Yes \\
\hline
\end{tabular}

From Table 9, it is seen that the maximum heat flux (Amount of heat transfer through per meter square area) is in the region above the rear left luggage compartment. Since there is no heat and sound source inside that compartment, extra isolation was not applied to this section. However when the mean temperatures of the regions were investigated it is seen that the average temperature of this region is $55.7^{\circ} \mathrm{C}$, and here is a high temperature region, because of the high amount of heat transfer from engine, radiator and transmission compartments. So it is advised an application of $20 \mathrm{~mm}$ thick, single layer isolation to this compartment to prevent the heat transfer to the passenger compartment. Similarly, $2 \mathrm{~mm}$ steel plate placed under the transmission inspection lid, increases the amount of heat transfer to the passenger compartment. Because, this plate works as a heat storage. As a result of this study it is advised to change the inspection lid structure into a different type having isolation material, instead of steel plate.

Since the heat transfer area is higher than the other regions, it can be thought that heat transfer from luggage room region is very high. However, when heat flux values given Table 9 and Figure 4 were investigated, it was seen that this value is very low compared to the other regions. So, since there is no heat and sound source in the luggage room, there is no need to employ an extra isolation material to the luggage compartment region, as is applied currently. These results proved that the current application (Plywood without any isolation material) is suitable from isolation and economy points of views.

The heat transfer value above the front axle region is a little high compared to the other regions. So it is advised a single layer, $20 \mathrm{~mm}$ thick isolation material to this region, this will positively affect both the heat and sound isolation. This isolation will work especially for the sound created by the tires.

In the examinations, it is seen that there is no isolation material application to the region under the driver platform. However, the heat flux value of this region is over the mean value of the whole bottom. Application of isolation to this region can supply an extra comfort to the driver in the very cold winter times by preventing the heat transfer from the passenger compartment to 
out of vehicle.

Over the battery case, double layer isolation was employed and as a result of this application, heat flux value of this region is determined very low. Since there is no noise source in this compartment, by considering the amount of heat transfer through this region, as advised for the rear left luggage, application of $20 \mathrm{~mm}$ thick, single layer isolation will provide a little amount of economic advantage.

In the rear axle region, although the heat transfer amount is very low, by considering the noise created by the differential and the tires, application of double layer isolation must be kept.

\section{Conclusion}

As a conclusion, the amount of convective and conductive heat transfer from the bottom of the passenger cabin and engine room of a $12-\mathrm{m}$ coach was calculated and examined in detail. At the end of the study; extra isolation materials are added to some regions to improve the passenger comfort by reducing the rate of heat transfer. In some of the regions, some portion of applied ineffective isolation materials are canceled without any lack of comfort and provide the manufacturer a cost saving. When evaluated from the heat and sound isolation point of views, it can be said that current engine room isolation material and application is suitable.

\section{Nomenclature}

U: Total Heat Transfer Coefficient $\left(\mathrm{W} / \mathrm{m}^{2} \mathrm{~K}\right)$

$h_{\text {in: }}$ Inner convection heat transfer coefficient $\left(\mathrm{W} / \mathrm{m}^{2} \mathrm{~K}\right)$

$\mathrm{s}$ : Thickness of the material $(\mathrm{m})$

$\mathrm{k}$ : Thermal conductivity (W/mK)

$\mathrm{h}_{\text {out }}$ :Outer convection heat transfer coefficient $\left(\mathrm{W} / \mathrm{m}^{2} \mathrm{~K}\right)$

$\mathrm{Nu}$ : Nusselt Number

$\mathrm{k}$ : Thermal conductivity of dry air at average temperature. $(\mathrm{W} / \mathrm{mK})$

$\mathrm{L}_{\mathrm{k}}$ : Characteristic Length (m)

$\mathrm{Nu}_{\text {L,Lam:Local Laminar Nusselt Number }}$

$\mathrm{Nu}$,L,Tur:Local Turbulent Nusselt Number

F: Heat transfer surface area $\left(\mathrm{m}^{2}\right)$

$\Delta \mathrm{T}$ : Temperature difference $\left({ }^{\circ} \mathrm{C}\right)$

Re: Reynolds Number

Pr: Prandtl Number

v: Kinematic viscosity $\left(\mathrm{m}^{2} \cdot \mathrm{s}^{-1}\right)$

$\mathrm{C}_{\mathrm{p}}$ : Specific heat $(\mathrm{kJ} / \mathrm{kgK})$

$\rho:$ Specific gravity $\left(\mathrm{kg} / \mathrm{m}^{3}\right)$
$\mathrm{T}_{\text {ort }}$ : Average temperature $\left({ }^{\circ} \mathrm{C}\right)$

P: Pressure (Bar)

$\eta$ : Dynamic viscosity $(\mathrm{kg} / \mathrm{m} / \mathrm{s})$

\section{References}

1. Binner, T., Reister, H., Weidmann, E. P., Wiedemann, J.,Aspects of Underhood Thermal Analyses, 2006.

2. Boltz et al, Air Conditioning Systems For Buses and Coaches, Verlag moderne industrie, 2011.

3. Büyükalaca, O., Y1lmaz, T., Ünal, Ş., Cihan, E., and Hürdoğan, E., Calculation of Cooling Load of a Bus Using Radiant Time Series (RTS) Method, 6th International Advanced Technologies Symposium (IATS'11), 16-18 May 2011.

4. Fournier, E. and Digges, K., Underhood Temperature Measurements of Four Vehicles, Motor Vehicle Fire Research Institute, Biokinetics and Associates, Ltd., Report R0413, 2004.

5. Kulkarni, C., Deshpande, M. D., Umesh, S. and Raval, C., Underhood Flow Management of Heavy Commercial Vehicle to Improve Thermal Performance, Sastech, Volume 11, Issue 1, 2012.

6. Xiao, G., Yang, Z., Wang, D., and Zhang, W., Investigation of Radiation and Conjugate Heat Transfers for Vehicle Underbody, SAE Technical Paper 2008-011819, 2008.

7. Reddy, S.S., Akhil, P., Raju, N., Vishnu, K., Ashok, N., Analysis of Air Conditioning System used in Automobile, International Journal of Trend in Scientific Research and Development (IJTSRD), Vol.3, Issue:3, 2019 eISSN: 2456-6470.

8. Mezarcıöz, S., Değişik Sürüş Şartları Altında Bir Yolcu Otobüsünün Motor Odas1 Sicaklık Dağılımının Belirlenmesi, Mühendis ve Makina, Cilt 59, sayı 693, s. 54-63, 2018.

9. Yilmaz T, Isı Transferi Kitabı, Papatya Yayınc1lık, 1999.

10. Mezarciöz, S., Improvement of a Coach Air-Conditioning System Applying a Distinct Air Channel, (Doctoral dissertation), Cukurova University, Institute of Natural and Applied Sciences, Department of Machine Engineering, Adana, Turkey, pp.214, 2015.

11. SAE J1503: Performance test for airconditioned, heated, and ventilated off-road, 
self-propelled work machines.

12. Temsa (2007): Klima maksimum performans testi şartnamesi TES-90-518, 2007.

13. ASHRAE 2001: ASHRAE

Fundamentals Handbook 2001, Nonresidential

Cooling And Heating Load Calculation

Procedures, Chapter.29. 